\title{
Mixotrophy: a widespread and important ecological strategy for planktonic and sea-ice nanoflagellates in the Ross Sea, Antarctica
}

\author{
Stefanie Moorthi ${ }^{1,4, *}$, David A. Caron ${ }^{1}$, Rebecca J. Gast ${ }^{2}$, Robert W. Sanders ${ }^{3}$ \\ ${ }^{1}$ Department of Biological Sciences, University of Southern California, Los Angeles, California 90089, USA \\ ${ }^{2}$ Biology Department, Woods Hole Oceanographic Institution, Woods Hole, Massachusetts 02543, USA \\ ${ }^{3}$ Department of Biology, Temple University, Philadelphia, Pennsylvania 19122, USA \\ ${ }^{4}$ Present address: Institute for Chemistry and Biology of the Marine Environment (ICBM-Terramare), \\ University of Oldenburg, 26382 Wilhelmshaven, Germany
}

\begin{abstract}
Mixotrophic nanoflagellates (MNF) were quantified in plankton and sea ice of the Ross Sea, Antarctica, during austral spring. Tracer experiments using fluorescently labeled bacteria (FLB) were conducted to enumerate MNF and determine their contribution to total chloroplastidic and total bacterivorous nanoflagellates. Absolute abundances of MNF were typically $<200 \mathrm{ml}^{-1}$ in plankton assemblages south of the Polar Front, but they comprised 8 to $42 \%$ and 3 to $25 \%$ of bacterivorous nanoflagellates in the water column and ice cores, respectively. Moreover, they represented up to $10 \%$ of all chloroplastidic nanoflagellates in the water column when the prymnesiophyte Phaeocystis antarctica was blooming (up to $23 \%$ if $P$. antarctica, which did not ingest FLB, was excluded from calculations). In ice cores, MNF comprised 5 to $10 \%$ of chloroplastidic nanoflagellates. The highest proportions of MNF were found in some surface water samples and in plankton assemblages beneath ice, suggesting a potentially large effect as bacterial grazers in those locations. This study is the first to report abundances and distributions of mixotrophic flagellates in the Southern Ocean. The presence of MNF in every ice and water sample examined suggests that mixotrophy is an important alternative dietary strategy in this region.
\end{abstract}

KEY WORDS: Ross Sea · Antarctica - Mixotrophy · Mixotrophic nanoflagellates · Bacterivory • Plankton $\cdot$ Sea ice $\cdot$ Fluorescently labeled bacteria

\section{INTRODUCTION}

Planktonic protists have traditionally been divided into either phototrophic or heterotrophic modes of energy and carbon acquisition. However, mixotrophic behavior, in which organisms combine both modes of nutrition within a single cell, has been increasingly recognized and documented in recent decades (see Sanders \& Porter 1988, Caron 2000, Stickney et al. 2000). Phagotrophic phytoflagellates are chloroplastidic protists (i.e. true algae) that possess the ability to ingest and digest particulate prey (Sanders \& Porter 1988). The balance between phototrophy and heterotrophy can vary greatly among mixotrophic (phagotrophic) algae. Most of these species can sustain some level of population growth photosynthetically without particulate food, some can grow in the dark with food, and at least 1 freshwater species appears to be an obligate mixotroph with requirements for both light and bacterial food (Sanders et al. 1990, Caron et al. 1993, Hansen et al. 2000). The potential nutritional benefits of particle ingestion by phytoplankton include the acquisition of organic carbon, energy, major nutrients, and micronutrients including vitamins and trace metals (Sanders et al. 1990, Caron et al. 1993, Maranger et al. 1998, Hansen et al. 2000, Jones 2000). Environmental factors such as light intensity, nutrient and prey concentrations as well as abundances of purely heterotrophic or phototrophic competitors can influence the nutritional mode of mixotrophs and the 
relative importance of photosynthesis and phagotrophy to the alga (e.g. Sanders et al. 1990, 2000, Caron et al. 1993, Rothhaupt 1996).

Mixotrophic behavior is widely distributed among algal taxa and has been reported for chrysophytes, dinoflagellates, prymnesiophytes, and cryptophytes (Sanders \& Porter 1988). Mixotrophic algae are ecologically significant both as primary producers and consumers, contributing up to $50 \%$ of the total phototrophic nanoplankton and up to $79 \%$ of the total bacterivory in marine and freshwater habitats (e.g. Sanders et al. 1989, 2000, Berninger et al. 1992, Havskum \& Riemann 1996, Bell \& Laybourn-Parry 2003). Their broad geographical distributions and sometimes high abundances indicate that mixotrophy is a successful strategy despite the potential metabolic cost of maintaining the enzymes and structures required to support both nutritional modes (Raven 1997).

In the Ross Sea Polynya, Antarctica, the annual phytoplankton bloom begins in austral spring (October-November) and reaches maximal biomass in austral summer (January-February; Smith et al. 2000). The bloom is typically dominated by the colonial prymnesiophyte Phaeocystis antarctica in the southern central polynya, while more coastal regions are dominated by diatoms and dinoflagellates (Dennett et al. 2001). Photosynthetic and heterotrophic nanoplankton are present during all phases of the bloom, ranging over 3 orders of magnitude from $2 \times 10^{3} \mathrm{l}^{-1}$ to $7 \times 10^{6} \mathrm{l}^{-1}$ and peaking in austral summer (Dennett et al. 2001). The importance of heterotrophic protists as bacterial consumers in Antarctic waters has recently been demonstrated (e.g. Becquevort et al. 2000, Vaqué et al. 2004). However, there is very little information on the composition of the bacterivorous community and no evidence for the occurrence of mixotrophy in the Southern Ocean. Our lack of knowledge regarding the contribution of mixotrophic algae to the carbon flow of microbial food webs of this ecosystem is in part due to the methodological approaches that have been commonly used to determine community bacterivory, viz. dilution experiments, differential filtration, and disappearance of tracer particles over an extended time. These methods are generally ineffective for identifying ingestion by phagotrophic algae. The few studies that have examined bacterivory in the Southern Ocean using the uptake of fluorescently labeled particles did not distinguish ingestion by photosynthetic plankton (Leakey et al. 1996, Becquevort et al. 2000).

Abundances of mixotrophic nanoflagellates (MNF) and their contributions to phototrophic and heterotrophic nanoflagellate (PNF and HNF) assemblages were assessed and compared in the proximity of the Antarctic Polar Front, within the Ross Sea Polynya, and at several stations between those sites in order to determine the extent to which mixotrophs are present in this region. This study provides the first record of MNF within microbial communities from plankton and/or sea ice in the Southern Ocean, and suggests an important role for previously unstudied trophic interactions in the microbial food web.

\section{MATERIALS AND METHODS}

Seventeen experiments were conducted that used fluorescently labeled bacteria (FLB) as food tracers to quantify phagotrophically-active phototrophic nanoflagellates (i.e. MNF, chloroplastidic species that have ingested FLB) at 13 different stations (Table 1, Fig. 1)

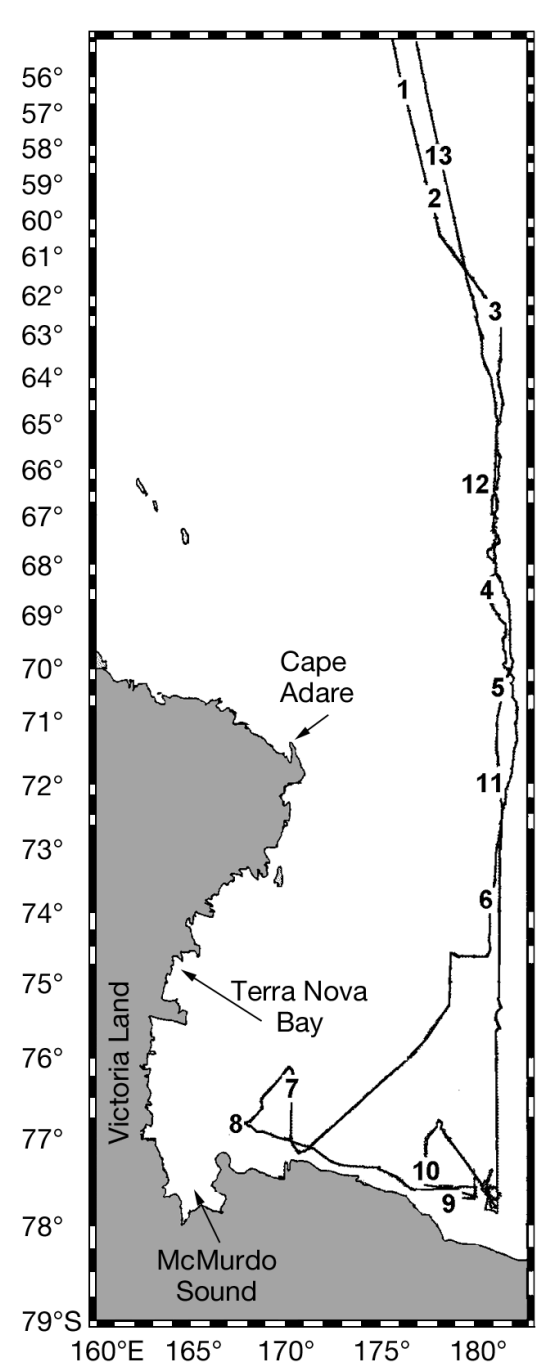

Fig. 1. Track of cruise NBP 05-08 with approximate station locations. Stations were sampled sequentially from 30 October to 7 December 2005. Time at station ranged from $<1$ to $6 \mathrm{~d}$. Raytheon Polar Services generated the chart; station locations and labels added by the authors 
Table 1. Station numbers, dates, positions, environments sampled, water depth, and chl a values from all experiments run in the Ross Sea, Antarctica, and just north and south of the polar front in 2005. nd: not determined; na: not applicable

\begin{tabular}{|c|c|c|c|c|c|c|}
\hline Expt & Stn & Date & Latitude (S)-Longitude (E) & Environment & Sample depth (m) & Chl a $\left(\mu \mathrm{g} \mathrm{l}^{-1}\right)$ \\
\hline I & 1 & 30 Oct & $56^{\circ} 29.52-176^{\circ} 23.07$ & Seawater & 4 & $0.30 \pm 0.01$ \\
\hline II & 2 & 31 Oct & $59^{\circ} 32.65-177^{\circ} 46.00$ & Seawater & 5 & $0.39 \pm 0.06$ \\
\hline III & 3 & $1 \mathrm{Nov}$ & $62^{\circ} 00.90-178^{\circ} 44.21$ & Seawater & 5 & $0.53 \pm 0.03$ \\
\hline IV & 4 & $4 \mathrm{Nov}$ & $68^{\circ} 46.71-179^{\circ} 04.56$ & Seawater & 5 & $0.33 \pm 0.02$ \\
\hline $\mathrm{V}$ & 5 & $6 \mathrm{Nov}$ & $70^{\circ} 14.81-177^{\circ} 56.36$ & Seawater & 5 & nd \\
\hline VI & 6 & $7 / 8 \mathrm{Nov}$ & $73^{\circ} 57.00-179^{\circ} 08.46$ & Seawater & 5 & $0.34 \pm 0.05$ \\
\hline VII & $7 \mathrm{~A}$ & $11 \mathrm{Nov}$ & $76^{\circ} 11.38-170^{\circ} 17.15$ & Seawater & 5 & $0.63 \pm 0.03$ \\
\hline VIII & $7 \mathrm{~B}$ & $14 \mathrm{Nov}$ & $76^{\circ} 02.46-170^{\circ} 18.07$ & $\begin{array}{l}\text { Seawater } \\
\text { Brine }\end{array}$ & $\begin{array}{l}\text { na } \\
\text { na }\end{array}$ & $\begin{array}{l}2.17 \pm 0.14 \\
\text { nd }\end{array}$ \\
\hline IX & 8 & $15 \mathrm{Nov}$ & $76^{\circ} 50.18-167^{\circ} 39.89$ & $\begin{array}{l}\text { Seawater } \\
\text { Brine }\end{array}$ & $\begin{array}{l}\text { na } \\
\text { na }\end{array}$ & $\begin{array}{l}\text { nd } \\
\text { nd }\end{array}$ \\
\hline $\mathrm{X}$ & $9 \mathrm{~A}$ & 19 Nov & $77^{\circ} 33.52-178^{\circ} 47.23$ & Seawater & 5 & $2.57 \pm 0.24$ \\
\hline XI & 9B & $23 \mathrm{Nov}$ & $76^{\circ} 47.92-178^{\circ} 15.46$ & $\begin{array}{l}\text { Seawater } \\
\text { Brine }\end{array}$ & $\begin{array}{l}\text { na } \\
\text { na }\end{array}$ & $\begin{array}{l}4.30 \pm 0.54 \\
\text { nd }\end{array}$ \\
\hline XII & $9 \mathrm{C}$ & $24 \mathrm{Nov}$ & $76^{\circ} 54.63-178^{\circ} 21.10$ & Seawater & 5 & $5.21 \pm 0.03$ \\
\hline XIII & 10 & $29 \mathrm{Nov}$ & $77^{\circ} 42.66-178^{\circ} 45.25$ & Seawater & 5 & $7.26 \pm 0.17$ \\
\hline XIV & $11 \mathrm{~A}$ & $2 \mathrm{Dec}$ & $72^{\circ} 28.01-178^{\circ} 31.23$ & Seawater & 2 & $0.63 \pm 0.01$ \\
\hline $\mathrm{XV}$ & $11 \mathrm{~B}$ & $2 \mathrm{Dec}$ & $71^{\circ} 50.95-178^{\circ} 39.16$ & $\begin{array}{c}\text { Seawater } \\
\text { Brine }\end{array}$ & $\begin{array}{l}\text { na } \\
\text { na }\end{array}$ & $\begin{array}{l}0.58 \pm 0.01 \\
\text { nd }\end{array}$ \\
\hline XVI & 12 & $4 \mathrm{Dec}$ & $66^{\circ} 41.95-178^{\circ} 47.10$ & $\begin{array}{c}\text { Seawater - surface } \\
\text { Seawater DCM }\end{array}$ & $\begin{array}{r}2 \\
40\end{array}$ & $\begin{array}{l}0.79 \pm 0.03 \\
0.76 \pm 0.01\end{array}$ \\
\hline XVII & 13 & $7 \mathrm{Dec}$ & $58^{\circ} 06.78-178^{\circ} 11.56$ & $\begin{array}{c}\text { Seawater - surface } \\
\text { Seawater DCM }\end{array}$ & $\begin{array}{r}2 \\
49\end{array}$ & $\begin{array}{l}\text { nd } \\
\text { nd }\end{array}$ \\
\hline
\end{tabular}

during the austral spring of 2005 (30 October to 7 December). FLB uptake experiments were conducted onboard the RVIB 'Nathaniel B. Palmer' (cruise NBP 05-08) with microbial assemblages from the water column (surface water and deep chlorophyll maximum), under the ice, and within sea ice (Fig. 1, Table 1). Stn 1 was north, and Stns 2 and 3 were south of the polar front at which sea surface temperature dropped from $+1^{\circ} \mathrm{C}$ to $-1^{\circ} \mathrm{C}$ within a few nautical miles. Stns 12 and 13 , sampled on the return trip north, were also on opposite sides of the polar front. Stns 6 to 10 were located in the polynya or near its edge. Other stations were located in the pack ice region of the Ross Sea with varying amounts of first-year pack ice and floes.

Sample collection. Water samples from ice-free regions were collected in Niskin bottles and, except for Expt 1, pre-filtered through $200 \mu \mathrm{m}$ Nitex mesh (Wildlife Supply) to remove metazooplankton prior to use in the FLB grazing experiments. Samples collected from under the ice were collected through a core hole by aspiration via $12 \mathrm{~mm}$ ID tubing into an acid-cleaned polycarbonate carboy. Ice cores were collected from ice floes using motorized Sipre corers. Ice cores were approximately 1 to $2 \mathrm{~m}$ long and sections showing color, indicating microbial biomass (red, brown, or green), were pooled and recovered for analysis. Ice samples were brought back to the ship in sterile containers and processed in a walk-in coldroom at approximately $4^{\circ} \mathrm{C}$. FLB grazing experiments require a liquid phase to allow for distribution of the food tracers (FLB); therefore, microorganisms were extracted from the sea ice. Ice chunks from each core were crushed inside sterile Whirlpak-bags (Nasco, 11 volume), and microorganisms were washed out of the brine channels by combining equal amounts of the crushed ice and icecold, sterile-filtered seawater (FSW) in a Whirlpak-bag and mixing thoroughly. This procedure substantially reduces osmotic shock to protists compared to melting of ice cores and allows the recovery of up to $323 \%$ more protist cells than melting ice alone (SimeNgando et al. 1997). The liquid phase (mixture of brine and filtered seawater) from all ice chunks was pooled for each experiment and then pre-filtered through $200 \mu \mathrm{m}$ Nitex mesh to remove larger zooplankton for the FLB experiment. The remaining rinsed, crushed ice was pooled and melted with a surplus of FSW (2:1) to determine the effectiveness of the collection by rinsing. Generally $<5 \%$ of the total number of microorganisms remained in the crushed ice.

Experimental setup and sample processing. Experiments were conducted in triplicate using 2.71 polycarbonate bottles filled with 21 of seawater or brine from ice cores. A subsample from each treatment was removed, and bacterial abundances were determined (see below) prior to adding FLB at approximately $25 \%$ of natural bacterial abundances (see Sherr \& Sherr 1993). Initial $\left(t_{0}\right)$ samples were taken directly after FLB addition; $180 \mathrm{ml}$ were preserved with $20 \mathrm{ml}$ of ice-cold glutaraldehyde at a final concentration of $1 \%$. Experimental bottles were incubated at $4^{\circ} \mathrm{C}$ and at a light 
intensity of $45 \mu \mathrm{E} \mathrm{m} \mathrm{m}^{-2} \mathrm{~s}^{-1}$ for $12 \mathrm{~h}\left(t_{12}\right)$. This light level was successfully used before to culture photosynthetic protists from Antarctica. A $12 \mathrm{~h}$ incubation time has been successfully used in prior FLB grazing experiments for the determination of mixotrophs (Sanders et al. 2000). The $t_{12}$ samples were processed in the same manner as the $t_{0}$ samples. All preserved samples were stored at $4^{\circ} \mathrm{C}$ until slides were prepared (within $24 \mathrm{~h}$ in order to avoid loss of chlorophyll autofluorescence). Depending on species abundances and organic material, 10 to $15 \mathrm{ml}$ of each sample were collected on a $0.2 \mu \mathrm{m}$ polycarbonate filter (Nuclepore Track-Etch Membrane, PC MB $25 \mathrm{~mm}$ ) to count bacteria, FLB, and flagellates $<3 \mu \mathrm{m}$, and 20 to $100 \mathrm{ml}$ were collected on $3 \mu \mathrm{m}$ polycarbonate filters to count nanoflagellates and diatoms. Filters were mounted onto a slide and covered with a single drop of Vectashield mounting medium with 4', 6-diamidino-2-phenylindole (DAPI; Vector Laboratories) and a cover slip. The DAPI stained the DNA of bacteria and protists, enabling them to be counted with epifluorescence microscopy (Porter \& Feig 1980). Prepared slides were stored at $-20^{\circ} \mathrm{C}$ until microscopical analysis. Slides from initial $\left(t_{0}\right)$ samples were used to account for any background coincidence of FLB/cells resulting solely from slide preparation.

For chlorophyll analyses, 50 to $250 \mathrm{ml}$ of seawater were collected on Whatman GF/F filters and frozen until extracted and analyzed. Extractions were performed overnight in $90 \%$ acetone in a freezer, followed by fluorescence determination with a Turner Designs 10-AU fluorometer.

Enumeration. PNF and HNF, diatoms, bacteria, and FLB were counted on the filter preparations with a Zeiss Axioskop 50 epifluorescence microscope at 1000x magnification. Bacteria and diatoms were counted using a UV filter set (340 to $380 \mathrm{~nm}$ excitation, $>420 \mathrm{~nm}$ emission), and FLB were counted using a blue filter set (450 to $490 \mathrm{~nm}$ excitation, $>515 \mathrm{~nm}$ emission). Flagellates were examined using both filter sets to differentiate and enumerate chloroplastidic and non-chloroplastidic organisms, and to determine whether they had ingested FLB. Flagellates $>3 \mu \mathrm{m}$ and diatoms were counted in 50 to 100 fields of view (10 to $>100$ cells for diatoms and 30 to $>200$ cells for different flagellates counted per filter), and flagellates $<3 \mu \mathrm{m}$, bacteria, and FLB were counted in 10 fields of view (50 to $>200$ cells counted per filter). PNF and HNF were differentiated by the presence or absence of chlorophyll autofluorescence, while MNF were defined as autofluorescent cells containing 1 or more ingested FLB. The average size distribution of the flagellates was assessed using an ocular micrometer. All abundances were calculated per milliliter seawater or milliliter brine. For the latter, the original brine volume was calculated by subtracting the amount of added FSW (used to wash organisms out of brine channels) from the total amount of the experimental FSW/brine mixture, assuming the remainder to be pure brine. The appropriate dilution factor then was used to calculate organisms per milliliter of the original brine.

FLB preparation. FLB were prepared from cultured Halomonas halodurans $(0.8 \mu \mathrm{m})$, which have been used successfully in bacterivory experiments and for identification of mixotrophs (Sanders et al. 2000). Briefly, $10 \mathrm{ml}$ of a dense bacterial culture were inoculated into $1 \mathrm{l}$ of $0.2 \mu \mathrm{m}$ filtered and autoclaved seawater (FSW) enriched with yeast extract. After $24 \mathrm{~h}$, the cells were harvested, washed by repeated centrifugation in FSW, and then stained with 5-(4,6-dichlorotriazin-2-yl)aminofluorescein (DTAF, $40 \mu \mathrm{g} \mathrm{ml}^{-1}$ ) at $64^{\circ} \mathrm{C}$ for $3 \mathrm{~h}$. FLB were then centrifuged and washed 4 to 5 times in FSW by repeated resuspension and centrifugation to remove excess DTAF. Finally, FLB were filtered through a sterile $3 \mu \mathrm{m}$ polycarbonate filter (Nuclepore Track-Etch Membrane, PC MB $25 \mathrm{~mm}$ ) to remove clumps, divided into $2 \mathrm{ml}$ aliquots, and stored at $-20^{\circ} \mathrm{C}$.

\section{RESULTS}

Absolute abundances of MNF in open surface waters were typically $<2 \times 10^{2}$ cells $\mathrm{ml}^{-1}$, and slightly higher at Stns 4, 5, and 6 (Fig. 2a). The highest abundances observed in this study occurred in the brine channels of sea ice, where MNF ranged from $10^{3}$ to $10^{4}$ cells ml $^{-1}$ of brine (Fig. 2a). HNF and PNF also reached highest abundances in sea ice, ranging from $10^{4}$ to $10^{5}$ cells $\mathrm{ml}^{-1}$ of brine (Fig. 2b, c). In seawater, HNF abundances were typically $<10^{3}$ cells $\mathrm{ml}^{-1}$. PNF abundances were slightly greater at many of the stations, even when Phaeocystis antarctica was not included in the calculations (Fig. 2C). P. antarctica sometimes exceeded $10^{4}$ cells ml $^{-1}$ and dominated the phytoplankton biomass in almost all of the seawater samples taken south of $74^{\circ} \mathrm{S}$ and in 1 of the sea-ice samples (Fig. 3a). In general, nanoflagellates had a similar size distribution in the different environments examined. More than $70 \%$ of the flagellates were 4 to $6 \mu \mathrm{m}$ in diameter, and the remainder rarely exceeded $10 \mu \mathrm{m}(<5 \%)$. Flagellates $<3 \mu \mathrm{m}$ usually comprised $<3 \%$ of the total nanoflagellates, except at $\mathrm{Stn} 9 \mathrm{~B}$, where abundances approached 4000 cells ml ${ }^{-1}$ under the ice $(20 \%$ of the total nanoflagellates) and 650 cells ml ${ }^{-1}$ within the ice (13\% of the total nanoflagellates), and at Stns 9A, 10, and $11 \mathrm{~A}$, where they were patchily distributed in only 1 of the 3 replicates at each station, respectively, with 20 to 1000 cells ml$^{-1}$. No FLB ingestion was detected by these small chloroplastidic flagellates. Diatoms were present in sea ice at similar abundances as nanoflagel- 

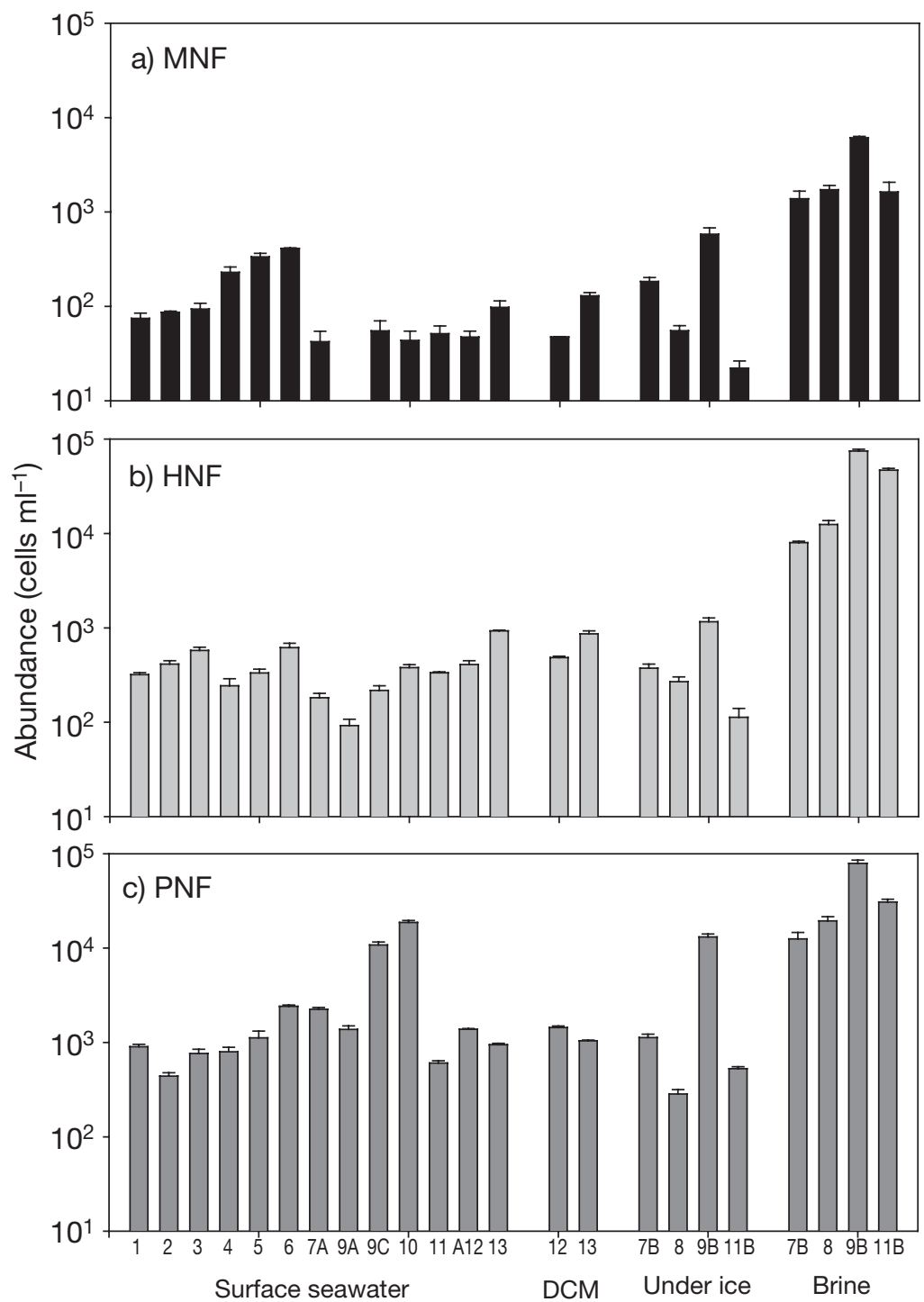

Stations

Fig. 2. Absolute abundance (cells $\mathrm{ml}^{-1}$, mean $+\mathrm{SE}$ ) of (a) mixotrophic (MNF), (b) heterotrophic (HNF) and (c) autotrophic (PNF, excluding Phaeocystis antarctica) nanoflagellates at different stations in surface seawater, the deep chlorophyll maximum (DCM), seawater under the ice, and in the brine of sea ice. Note that different habitats were sometimes investigated at the same station

lates, but in seawater their abundances varied from

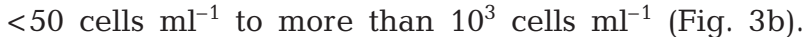
Chlorophyll concentrations exceeded $0.8 \mu^{-l^{-1}}$ only when $P$. antarctica was abundant (Table 1, Fig. 3a). Bacterial abundances usually ranged between $10^{5}$ and $10^{6} \mathrm{cells} \mathrm{ml}^{-1}$ in surface seawater and under ice, and were greater only in 2 of the brine samples (Stns 9B and 11B; Fig. 3c).

Mixotrophs comprised 8 to $42 \%$ of bacterivorous nanoflagellates $(\mathrm{BNF}=\mathrm{HNF}+\mathrm{MNF}$; Fig. 4$)$ and 4 to $>23 \%$ of all chloroplastidic nanoflagellates $(\mathrm{CNF}=$
PNF + MNF; Fig. 5) excluding Phaeocystis antarctica. When $P$. antarctica, which did not ingest FLB, was included among the PNF, mixotrophs constituted a maximum of approximately $10 \%$ of the CNF. The greatest contributions of MNF to total BNF were observed in surface seawater at Stns 4, 5, and 6, as well as in seawater under the ice at Stns 7B and 9B (30 to $40 \%$ of BNF). Mixotrophs in ice cores represented 5 to $10 \%$ and 3 to $15 \%$ of the PNF and $\mathrm{BNF}$, respectively, and mixotrophs comprised greater proportions of the BNF and CNF in seawater under the ice than in the brine. There were no apparent differences in the contributions of mixotrophs to $\mathrm{BNF}$ and CNF in the deep chlorophyll maximum (DCM) compared to surface waters at Stns 12 and 13, where MNF constituted 6 to $22 \%$ and 9 to $14 \%$ of phototrophic and phagotrophic nanoplankton, respectively (Figs. $4 \& 5$ ).

\section{DISCUSSION}

Few published studies have examined the distribution and abundance of any protists that combine phototrophy and phagotrophy in the Antarctic region. However, kleptoplastidic protists, which sequester functional chloroplasts from ingested prey, and photosynthetic ciliates that ingest cryptophyte prey are known from Antarctica. The ciliate Mesodinium was isolated from McMurdo Sound (Gustafson et al. 2000), and a novel kleptoplastidic dinoflagellate was isolated from the Ross Sea and found to have wide distribution there (Gast et al. 2006). MNF were reported from 2 Antarctic lakes, and the cryptophyte Pyramimonas gelidicola was reported to consume 4 to $>100 \%$ of the bacterial production in a saline Antarctic lake (Marshall \& Laybourn-Parry 2002, Bell \& Laybourn-Parry 2003).

In the present study, MNF were observed in all seawater and sea-ice samples investigated. Their maximal contribution to total CNF was less than their maximal contribution to total BNF (20\% versus 30 to $40 \%$ ), even when abundances of Phaeocystis antarctica were excluded. Thus, mixotrophs likely played a substantial role as bacterial grazers, especially at Stns 4, 5, and 6 and in plankton assemblages under the ice. Ingestion rates were not determined in this study, but the large 

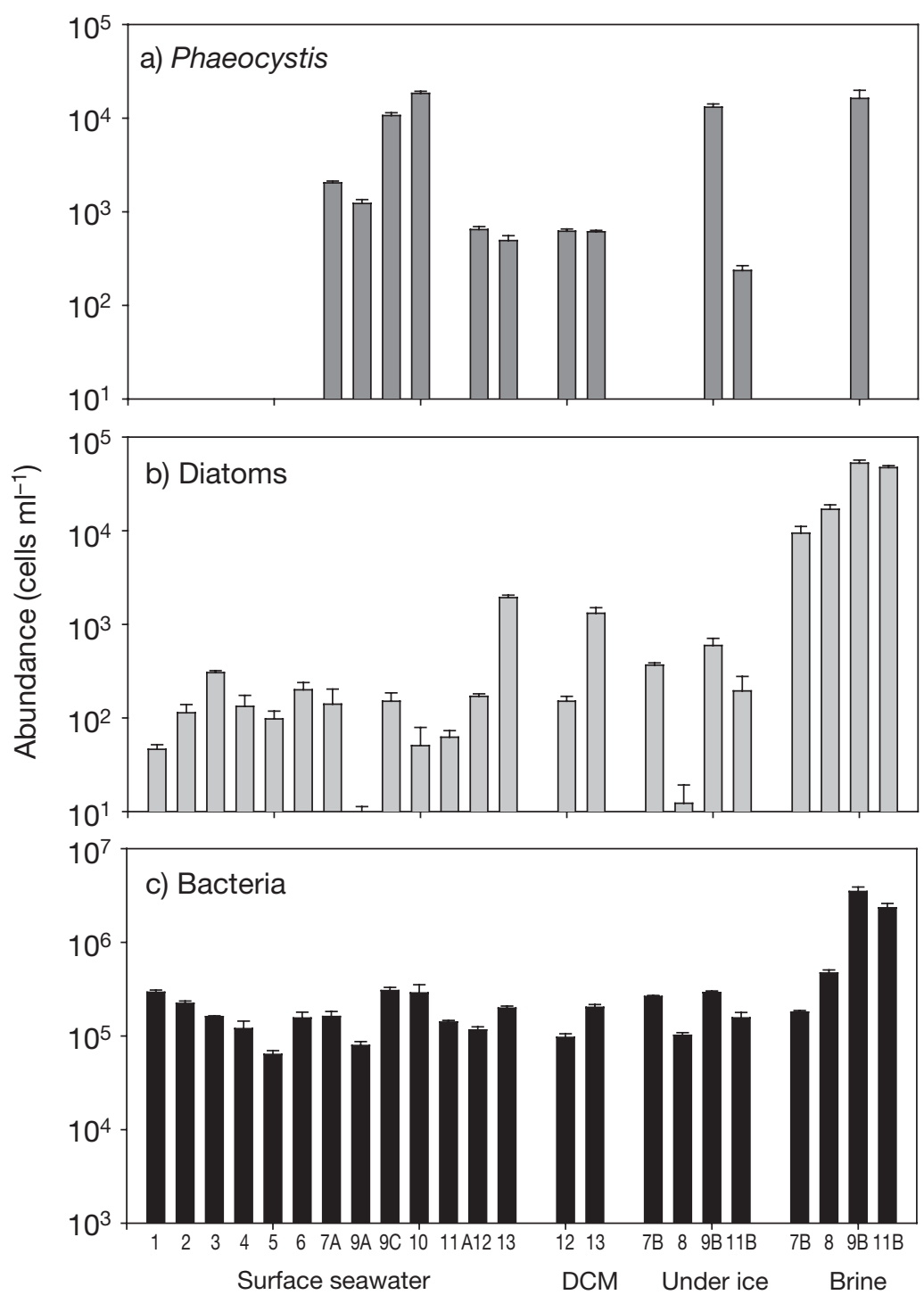

Stations

Fig. 3. Absolute abundance (cells $\mathrm{ml}^{-1}$, mean $+\mathrm{SE}$ ) of (a) Phaeocystis antarctica, (b) diatoms and (c) bacteria at different stations in surface seawater, the deep chlorophyll maximum (DCM), seawater under the ice, and in the brine of sea ice. Note the different scales on the $y$-axes, and also that different habitats were sometimes investigated at the same station

proportion of bacterivores that were mixotrophs indicates a potentially large contribution to bacterial mortality because several mixotrophs possess grazing rates equal to or exceeding co-occurring HNF (Sanders et al. 1989, Havskum \& Riemann 1996, Bell \& LaybournParry 2003). We estimated that mixotrophic nanoplankton might graze 11 to $>100 \%$ of the planktonic bacterial standing stock per day (average $54 \%$ ) using a rate of 1 bacteria $\mathrm{MNF}^{-1} \mathrm{~h}^{-1}$, which is at the low end of the range reported for Antarctic HNF (1.1 to 8 bacteria $\mathrm{HNF}^{-1} \mathrm{~h}^{-1}$; Leakey et al. 1996, Becquevort 1997). The potential grazing impact of mixotrophs in the sea ice was more difficult to estimate. Horizontal patchiness in the ice and our use of colored bands (vertical patches) within ice cores complicated predictions of overall impact of mixotrophs as bacterivores in this habitat.

While the potential grazing effect of purely heterotrophic protists in the Southern Ocean has been previously recognized in several studies (e.g. Becquevort et al. 2000, Vaqué et al. 2004), this study is the first report to identify the presence of bacterivorous mixotrophic algae.

Several methods have been used to determine bacterivory by protists, and each has advantages and disadvantages. One advantage of using the uptake of fluorescently labeled prey is that it allows identification of feeding by individual protists, and consequently the identification of mixotrophs when combined with the autofluorescence of photosynthetic pigments. However, the possibility of feeding selectivity against the fluorescent surrogates (relative to natural prey) based on size, phenotypic traits, motility, or taste discrimination has been noted for some heterotrophic protists (see Sherr \& Sherr 1993). Also, FLB that were taken up by mixotrophs could have been digested or egested in the $12 \mathrm{~h}$ incubation time, although they would presumably continue to encounter and ingest FLB throughout the incubation period. These caveats imply that the proportions of mixotrophs reported here should be considered conservative estimates of the true abundances in the Southern Ocean. Although we did not observe ingestion by chloroplastidic flagellates $<3 \mu \mathrm{m}$, ingestion of bacteria by photosynthetic picoeukaryotes has recently been reported (Zubkov \& Tarran 2008). It is possible that the $<3 \mu \mathrm{m}$ flagellates did not show ingestion because the relatively large FLB $(0.8 \mu \mathrm{m})$ used in the experiments were too large for them to ingest. These minute flagellates were generally not abundant in our samples and thus should not have affected our estimates dramatically.

High abundances of MNF have been observed at low light intensities in some previous studies (Bird \& Kalff 1986, Pålsson \& Granéli 2004). Organisms in Antarctic ecosystems must cope with extremely low 

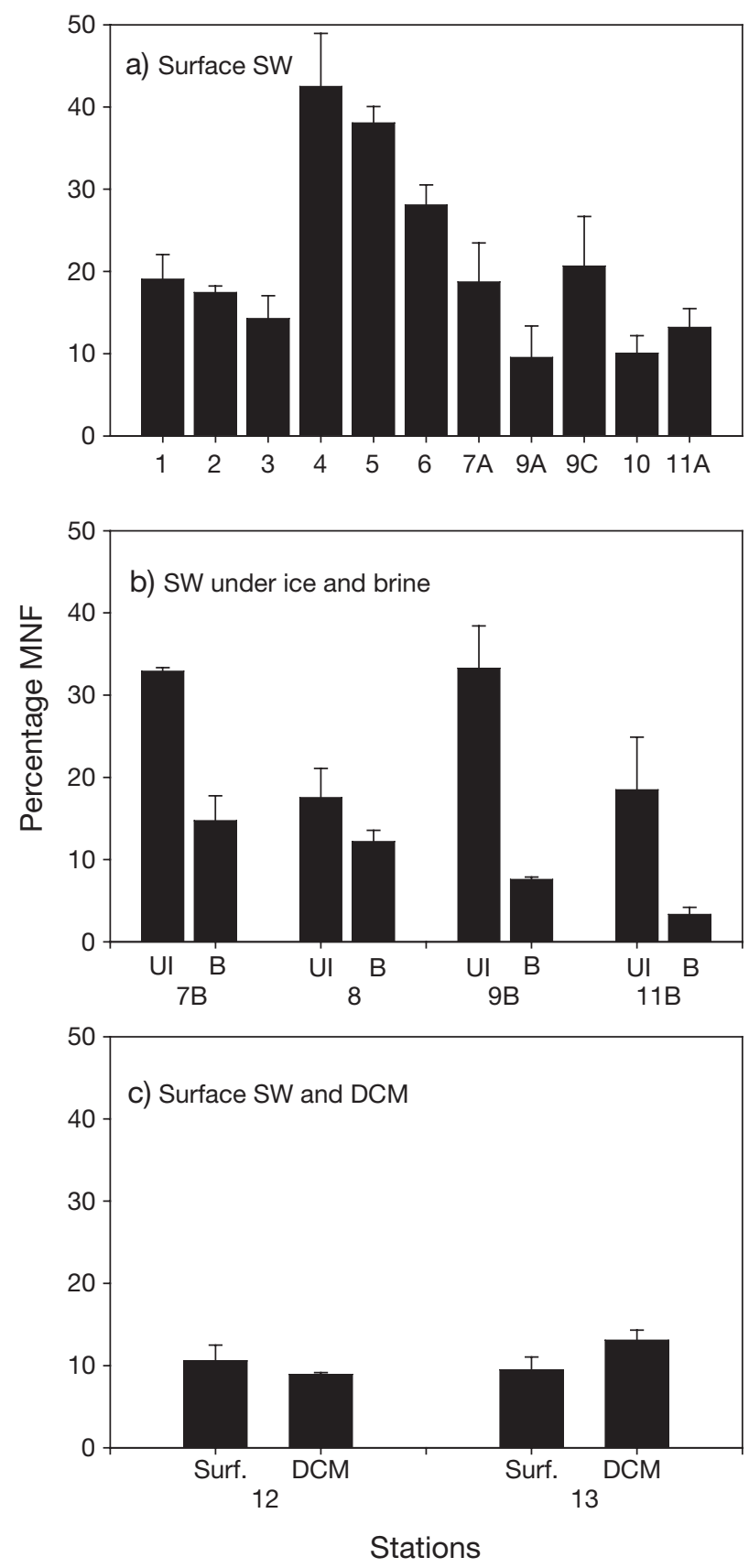

Fig. 4. Relative abundance (mean $+\mathrm{SE}$ ) of mixotrophic nanoflagellates (MNF) as a percentage of total bacterivorous nanoflagellates $(\mathrm{BNF}=$ heterotrophic nanoflagellates $+\mathrm{MNF})$ at different stations in (a) surface seawater (SW), (b) in seawater under the ice (UI), and in the brine of sea ice (B), and (c) in surface seawater (surf.) and the deep chlorophyll maximum (DCM)

light intensities during austral winter, and also in and under sea ice throughout the year. Mixotrophy as an alternative or auxiliary dietary strategy could be particularly important in polar marine environments at low light intensities, where it could facilitate survival
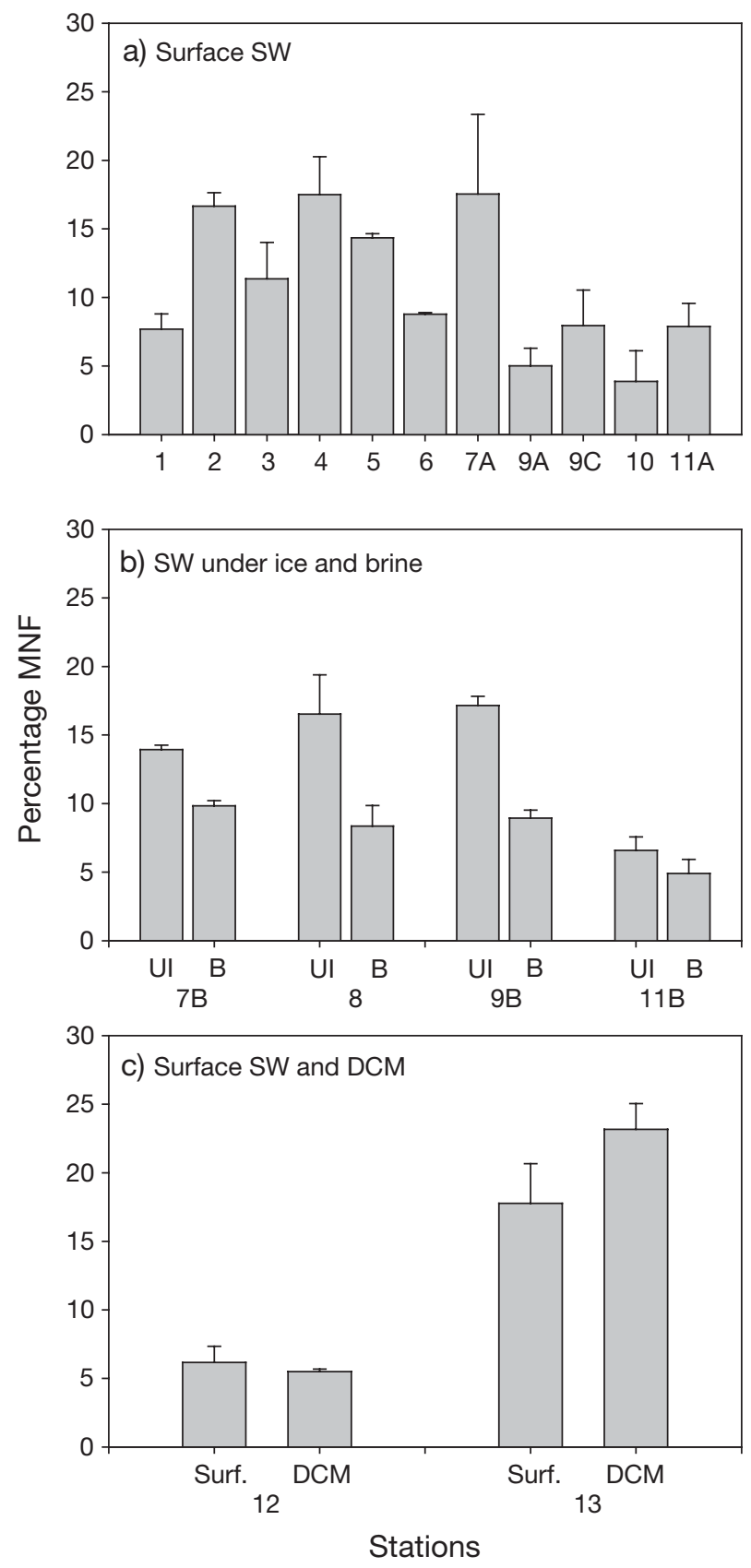

Fig. 5. Relative abundance (mean $\pm \mathrm{SE}$ ) of mixotrophic nanoflagellates (MNF) as a percentage of total chloroplastidic nanoflagellates $(\mathrm{CNF}=$ phototrophic nanoflagellates $+\mathrm{MNF})$ at different stations in (a) surface seawater (SW), (b) in seawater under the ice (UI), and in the brine of sea ice (B) and (c) in surface seawater (surf.) and the deep chlorophyll maximum (DCM)

under conditions that are less conducive for the growth of purely photosynthetic protists. For example, cryptophyte populations in the Dry Valley and other Antarctic lakes have been found to be mixotrophic, whereas they generally appear to display lower levels of phago- 
trophy at low latitudes (Sanders 1991, Marshall \& Laybourn-Parry 2002). Furthermore, a study examining the dark survival of Arctic phytoplankton showed a lack of growth by diatom species, but chloroplastidic nanoplankton (potentially mixotrophic) exhibited positive growth in the dark, which increased when light was provided (Qing et al. 2003).

The fraction of mixotrophs within the sea ice brine was lower than that found under the ice at every station where both were enumerated in the present study (Figs. 4, 5). This finding may indicate that phytoplankton face stronger light limitation in the underlying seawater compared to algae in the sea ice itself. Sea ice algae are physiologically adapted to living at low light (Thomas \& Dieckmann 2002), and may employ heterotrophic uptake of dissolved organics or phagotophy during periods of very low light (Palmisano \& Garrison 1993). Nevertheless, algae in the water beneath the ice must experience even lower light levels than the ice algae. Sea ice is an effective filter to light transmission, especially when covered with snow; under-ice irradiance is typically less than $1 \%$ and often even less than $0.1 \%$ of surface downwelling irradiance during the spring ice microalgal bloom (Sullivan et al. 1982). Therefore, mixotrophic phytoflagellates in the seawater beneath the sea ice may be strongly stimulated to feed phagotrophically.

This scenario for light limitation leading to higher proportions of mixotrophs is not in total accord with our data. Some of the highest percentages of phagotrophically active mixotrophs were observed in planktonic assemblages collected from open water. Numerous factors can alter phagotrophy by mixotrophs, and it is probable that macro- and micro-nutrient concentrations and prey abundance may have influenced the proportion of mixotrophs observed in the different environments that were sampled. For example, abundances and/or ingestion rates of Dinobryon, a freshwater mixotrophic chrysophyte, appeared dependent on water temperature (Bird \& Kalff 1987), and nutrient availability has been shown to alter ingestion for some mixotrophic marine haptophytes and stramenopiles in Norwegian waters (Nygaard \& Tobiesen 1993). Phytoplankton production in Antarctic waters may be limited by iron rather than major nutrients (Martin et al. 1990). Iron can be acquired via ingestion of bacteria by at least 1 marine mixotroph (Maranger et al. 1998), and is thus a potentially strong modifier of mixotrophic behavior and competition. Abundances of prey and purely heterotrophic or phototrophic competitors can also affect MNF abundances and feeding behavior (Rothhaupt 1996, Sanders et al. 2000).

Mixotrophy has been incorporated into models of microbial food webs to explore the potential effect of their trophic activity on community structure, bloom formation, and primary production. Two modeling studies determined that primarily heterotrophic mixotrophs can have a great effect on primary production, and that this type of mixotrophy can lead to a noticeable increase in primary production even at $1 \%$ of the population (Stickney et al. 2000, Hammer \& Pitchford 2005). Determining the quantitative contributions of phagotrophy and phototrophy was beyond the scope of our study. However, MNF occurred as a notable proportion of the nanoplankton, certainly more than $1 \%$, in all of our samples from the Ross Sea during austral spring, indicating that even very small portions of this trophic group may play a significant role in the creation and cycling of primary production in this region.

The data from this study demonstrate the widespread geographic and environmental distribution of an important functional trophic group (MNF), and point to a fundamental gap in our knowledge of the structure and function of food webs in the Ross Sea, Antarctica. Predictions of where and when mixotrophs will play an important role in microbial food webs are complicated by species-specific differences in resource requirements plus the broad array of factors that influence mixotrophic abundances and feeding behavior. Future research is needed to more fully characterize abundances and factors that promote and sustain growth of mixotrophs, and to thereby confirm their overall importance in the food webs of the polar regions.

Acknowledgements. We thank J. Rose, P. Countway, and the captain and crew of the 'Nathaniel B. Palmer' for their support in this field effort, and J. Goés for providing some of the chl a data. This work was supported by NSF grant OPP-0125833 to D.A.C. and R.J.G.

\section{LITERATURE CITED}

Becquevort S (1997) Nanoprotozooplankton in the Atlantic sector of the Southern Ocean during early spring: biomass and feeding activities. Deep Sea Res II 44:355-373

$>$ Becquevort S, Menon P, Lancelot C (2000) Differences in the protozoan biomass and grazing during spring and summer in the Indian sector of the Southern Ocean. Polar Biol 23: 309-320

Bell EM, Laybourn-Parry J (2003) Mixotrophy in the Antarctic phytoflagellate, Pyramimonas gelidicola (Chlorophyta: Prasinophyceas). J Phycol 39:644-649

$>$ Berninger UG, Caron DA, Sanders RW (1992) Mixotrophic algae in three ice-covered lakes of the Pocono Mountains, U.S.A. Freshw Biol 28:263-272

Bird DF, Kalff J (1986) Bacterial grazing by planktonic lake algae. Science 231:493-494

Bird DF, Kalff J (1987) Algal phagotrophy: regulating factors and importance relative to photosynthesis in Dinobryon (Chrysophyceae). Limnol Oceanogr 32:277-284

Caron DA (2000) Symbiosis and mixotrophy among pelagic microorganisms. In: Kirchman DL (ed) Microbial ecology of the oceans. Wiley-Liss, New York, p 495-523 
Caron DA, Sanders RW, Lim EL, Marrase C and others (1993) Light-dependent phagotrophy in the freshwater mixotrophic chrysophyte Dinobryon cylindricum. Microb Ecol 25:93-111

Dennett MR, Mathot S, Caron DA, Smith WO Jr, Lonsdale DJ (2001) Abundance and distribution of autotrophic and heterotrophic nano- and microplankton in the southern Ross Sea. Deep Sea Res II 48:4019-4037

Gast RJ, Moran DM, Beaudoin DJ, Blythe JN, Dennett MR, Caron DA (2006) Abundance of a novel dinoflagellate phylotype in the Ross Sea, Antarctica. J Phycol 42: 233-242

Gustafson DE, Stoecker DK, Johnson MD, van Heukelem WF, Sneider K (2000) Cryptophyte algae are robbed of their organelles by the marine ciliate Mesodinium rubrum. Nature 405:1049-1052

Hammer AC, Pitchford JW (2005) The role of mixotrophy in plankton bloom dynamics and the consequences for productivity. ICES J Mar Sci 62:833-840

Hansen PJ, Skovgaard A, Glud RN, Stoecker DK (2000) Physiology of the mixotrophic dinoflagellate Fragilidium subglobosum, II. Effects of time scale and prey concentration on photosynthetic performance. Mar Ecol Prog Ser 201: 137-146

Havskum H, Riemann B (1996) Ecological importance of bacterivorous, pigmented flagellates (mixotrophs) in the Bay of Aarhus, Denmark. Mar Ecol Prog Ser 137:251-263

Jones RI (2000) Mixotrophy in planktonic protists: an overview. Freshw Biol 45:219-226

Leakey RJG, Archer SD, Grey J (1996) Microbial dynamics in coastal waters of East Antarctica: bacterial production and nanoflagellate bacterivory. Mar Ecol Prog Ser 142:3-17

Maranger R, Bird DF, Price NM (1998) Iron aquisition by photosynthetic marine phytoplankton from ingested bacteria. Nature 396:248-251

Marshall W, Laybourn-Parry J (2002) The balance between photosynthesis and grazing in Antarctic mixotrophic cryptophytes during summer. Freshw Biol 47:2060-2070

Martin JH, Fitzwater SE, Gordon RM (1990) Iron deficiency limits phytoplankton growth in Antarctic waters. Glob Biogeochem Cycles 4:5-12

Nygaard K, Tobiesen A (1993) Bacterivory in algae: a survival strategy during nutrient limitation. Limnol Oceanogr 38: 273-279

Palmisano AC, Garrison DL (1993) Microorganisms in Antarctic sea ice. In: Friedmann EI (ed) Antarctic microbiology, Wiley, New York, p 167-218

Pålsson C, Granéli W (2004) Nutrient limitation of phototrophic and mixotrophic phytoplankton in a temperate and tropical humic lake gradient. J Plankton Res 26:1005-1014

Porter KG, Feig YS (1980) The use of DAPI for identifying and counting aquatic microflora. Limnol Oceanogr 25:943-948

Editorial responsibility: Urania Christaki, Wimereux, France
Qing Z, Gradinger R, Qingsong Z (2003) Competition within the marine microalgae over the polar dark period in the Greenland Sea of high Arctic. Acta Oceanol Sin 22:233-242

Raven JA (1997) Phagotrophy in phototrophs. Limnol Oceanogr 42:198-205

Rothhaupt KO (1996) Laboratory experiments with a mixotrophic chrysophyte and obligately phagotrophic and phototrophic competitors. Ecology 77:716-724

Sanders RW (1991) Mixotrophic protists in marine and freshwater ecosystems. J Protozool 38:76-81

Sanders RW, Porter KG (1988) Phagotrophic phytoflagellates. Adv Microb Ecol 10:167-192

Sanders RW, Porter KG, Bennett SJ, DeBiase AE (1989) Seasonal patterns of bacterivory by flagellates, ciliates, rotifers, and cladocerans in a freshwater planktonic community. Limnol Oceanogr 34:673-687

Sanders RW, Porter KG, Caron DA (1990) Relationship between phototrophy and phagotrophy in the mixotrophic chrysophyte Poterioochromonas malhamensis. Microb Ecol 19:97-109

Sanders RW, Berninger UG, Lim EL, Kemp PF, Caron DA (2000) Heterotrophic and mixotrophic nanoplankton predation on picoplankton in the Sargasso Sea and on Georges Bank. Mar Ecol Prog Ser 192:103-118

Sherr BF, Sherr EB (1993) Protistan grazing rates via uptake of fluorescently labeled prey. In: Kemp PF, Sherr BF, Sherr EB, Cole JJ (eds) Handbook of methods in aquatic microbial ecology. CRC Press LLC, Boca Raton, FL, p 695-701

> Sime-Ngando T, Juniper SK, Demers S (1997) Ice-brine and planktonic microheterotrophs from Saroma-ko Lagoon, Hokkaido (Japan): quantitative importance and trophodynamics. J Mar Syst 11:149-161

Smith WO Jr, Marra J, Hiscock MR, Barber RT (2000) The seasonal cycle of phytoplankton biomass and primary productivity in the Ross Sea, Antarctica. Deep Sea Res II 47: $3119-3140$

Stickney HL, Hood RR, Stoecker DK (2000) The impact of mixotrophy on planktonic marine ecosystems. Ecol Model 125:203-230

Sullivan CW, Palmisano AC, Kottmeier S, Moe R (1982) Development of the sea ice microbial communities (SIMCO) in McMurdo Sound, Antarctica. Antarct J US 17: 155-157

Thomas DN, Dieckmann GS (2002) Antarctic sea ice - a habitat for extremophiles. Science 295:641-644

> Vaqué D, Agustí S, Duarte CM (2004) Response of bacterial grazing rates to experimental manipulation of an Antarctic coastal nanoflagellate community. Aquat Microb Ecol 36:41-52

Zubkov MV, Tarran GA (2008) High bacterivory by the smallest phytoplankton in the North Atlantic Ocean. Nature 455:224-226

Submitted: July 14, 2008; Accepted: December 18, 2008 Proofs received from author(s): February 20, 2009 